\title{
SANCTIONS ON DIGITAL PLATFORMS: BALANCING PROPORTIONALITY IN A MODERN PUBLIC SQUARE
}

\author{
Enguerrand Marique*, UCLouvain / CRIDES (Belgium) \\ Place Montesquieu, 2 bte L2.07.01/ C.351 \\ B-1348-Louvain-la-Neuve - Belgium \\ enguerrand.marique@uclouvain.be \\ ¿o \\ Yseult Marique, University of Essex (United Kingdom); FÖV Speyer (Germany)
}

\begin{abstract}
This paper asks which legal tools digital operators could use to manage colliding rights on their platforms in a digitalised and transnational space such as the Internet. This space can be understood as a "modern public square", bringing together actions in the digitalised world and their interactions with actual events in the physical world. It is then useful to provide this space with a discursive framework allowing for discussing and contesting actions happening on it. In particular, this paper suggests that two well-known legal concepts, proportionality and sanctions, can be helpfully articulated within that discursive framework. In a first step, proportionality, a justificatory tool, is often used to suggest a way for managing colliding rights. This paper argues that for proportionality to be useful in managing colliding rights on digital platforms, its role, scope and limits need to be better framed and supplemented by an overall digital environment which can feed into the proportionality test in an appropriate way. This can be provided, thanks to a second step, namely labelling in law the actions digital operators take as sanctions. Sanctions are the reactions organised by digital operators to bring back social order on the platforms. The labelling of these reactions under the legal category of "sanctions" offers a meaningful tool for thinking about what digital operators do when they manage colliding rights by blocking or withdrawing contents and/or accounts. As different types of sanctions can be distinguished, differentiated legal consequences, especially in relation to managing colliding rights, can be identified. Here the role played by the proportionality test can be distinguished depending on the type of sanctions. In any case, for sanctions and proportionality to help address colliding rights on the modern public square, a discursive framework needs to be developed, which depends on the existence of relevant meaningful communities engaging in reflecting on the use of sanctions and proportionality.
\end{abstract}

Key words

Digital platforms, transnational normativity, pluralism, regulation, sanctions, proportionality, subsidiarity 


\section{Authors details for editorial office}

\section{Enguerrand Marique}

CRIDES - Institut pour la recherche interdisciplinaire en sciences juridiques - UCLouvain Place Montesquieu, 2 bte L2.07.01/ C.351

B-1348-Louvain-la-Neuve

Belgium

Tél. +3210474097

enguerrand.marique@,uclouvain.be

Dr Yseult Marique

University of Essex (United Kingdom)

FÖV Speyer (Germany)

University of Essex

School of law

Wivenhoe Park

CO4 3SQ

Colchester

United Kingdom

ymarique@essex.ac.uk 


\section{INTRODUCTION}

Made infamous by the El Paso shooting in the United States in the Summer 2019, 8chan was a far-right website which had developed its central identity around extremism. This site was "modelled on another message board called 4chan. But in a key difference, 4chan's founder bad the power to delete individual boards, while [8chan's founder] was committed to near absolute free speech. When 4 chan banned the discussion of the misogynistic harassment campaign known as Gamergate in 2014, 8chan gained in popularity as a staging ground for the campaign". ${ }^{1}$ These different policies about acceptable behaviours on the platforms illustrate how the online world intensifies social, political or cultural offline claims. In the days following the shooting, 8chan was flagged up for encouraging hate speech. As a reaction to popular outcry against this practice, the internet infrastructure provider suspended its services to 8chan. Digital operators are at the interface between sources of legal and social norms shaping individual and collective behaviours. As a contrast to the 8chan story, Pinterest cut searches into antivaccines when a measles epidemic broke out in a range of countries following a controversial anti-vaccine campaign. ${ }^{2}$ According to Pinterest, public health policy had to prevail over freedom of expression. This kind of reactions undertaken by digital operators are not neutral; they may have drastic consequences on social, political, cultural or economic interests of their targeted users.

Platforms react to users' behaviours using their power of coercion. They actively interfere for preventive, curative or punitive purposes in the interactions between users on the platforms. They limit, restrict, withdraw, curtail, adapt, blacklist, stop or block users' actions for a while or definitively. They seek to discipline some undesirable behaviours (negative) and ensure desirable interactions on the platform (positive). What constitutes desirable interactions or undesirable behaviour is left to them to appreciate. In general, platform operators seek to foster a sense of belonging to a shared community. They will thus seek to foster a sense of trust among the users, especially that the platform constitutes a safe environment for economic transactions. ${ }^{3}$ Important values in the offline world such as truth, privacy, property or freedom of expression may be replicated or not so much. If reactions taken at an individual level may seem innocuous, akin to a traffic ticket for a minor speeding offence, they can, taken in an aggregate manner, direct and regulate interactions on digital platforms and their effects beyond the digital platforms in the offline world. The responses adopted by digital operators to undesirable behaviour in the online world are not merely the product of the "invisible (digital) hand". Digital operators create a social order and seek to preserve its integrity, challenging the benevolent picture of social, economic and political life in the online world.

This collective dimension of reactions taken by digital operators in the online world leads this paper to questioning how they operate in legal terms, especially in terms of their democratic and social values. This paper does not address issues pertaining to creating economic value, although these decisions may be taken with such purposes in mind. It asks which legal tools digital operators could use to manage colliding rights on their platforms in a digitalised and transnational world such as the Internet. This space can be understood as a "modern public square", linking together actions in the digitalised world and their interactions with actual events in the physical space. It is then useful to provide this modern public square with a discursive framework allowing for discussing and contesting actions happening on it. In particular, this paper suggests that two well-known legal concepts, sanctions and proportionality, can be helpfully articulated within that discursive framework.

First, labelling in law the actions digital operators adopt against undesirable behaviour in the modern public square as sanctions, ie reactions to ensure and bring back social order on digital platforms, offers a meaningful legal tool for thinking about what digital operators do when they manage colliding rights by blocking or withdrawing contents and/or accounts. As different types of sanctions can be distinguished,

\footnotetext{
1 J Wong, " 8chan: the far-right website linked to the rise in hate crimes » The Guardian, London, 5August 2019 (available at https://www.theguardian.com/technology/2019/aug/04/mass-shootings-el-paso-texas-dayton-ohio8chan-far-right-website ).

2 C Newton, «Pinterest's work in public health shows the good a smaller social network can do » The Verge, 29 August 2019 (available at https://www.theverge.com/interface/2019/8/29/20837660/pinterest-vaccine-informationsearch-results-public-health ).

${ }^{3} \mathrm{R}$ Botsman, Who can you trust?: how technology brought us together-and why it could drive us apart (London: Penguin 2017).
} 
differentiated legal consequences can be identified, especially in relation to managing solutions when rights held by different users collide with each other. In following this approach, this paper departs from current analyses of digital platforms, often grounded in behavioural or regulatory perspectives: nudging and influencing users attract most of the academic attention for their apparent novelty. "Soft" tools (online reputation system including reviews and ratings) may indeed play a specific role in policing platforms. Yet, sanctions as coercive responses to undesirable behaviours are very much part of the toolkit of digital operators. This shifts the focus to the practices of digital operators.

This phenomenon is even likely to increase as users become savvier, want to do more and test platforms' boundaries. This leads to sanctions appearing increasingly often on the radar. Users will see how far they can go. They may exit platforms when they have been punished, they may also want to stay on these platforms (maybe there are not that many alternatives) but seek to voice their discontent: for instance, through participatory structures where they may have their say about what is (or not) allowed on the digital platform and how behaviours should/could be monitored and policed. Sanctions would then be a catalyst for developing a bottom up form of organisation interested in how the collective interactions are regulated: here again sanctions and how they are reacted to may lead away from soft law regulation and the "invisible hand" approaches on digital platforms. Coordination of colliding rights may - at least partly - be analysed through classic legal lenses, such as sanctions, even if this concept may not encompass all actions available to digital operators. In using these lenses, this paper flags up how "hard law" and techniques remain relevant when it comes to adjudicating conflicts among users and between users and platform operators.

Secondly, proportionality, a justificatory tool, is often used to suggest a way for managing collisions between rights. Since Lessig's seminal work, ${ }^{5}$ the Internet governance has been analyzed through the paradigm of constitutional law, ie an institutional (governance) approach ${ }^{6}$ (who is competent to act? what are the decision-making processes?) or perspectives focused on human rights ${ }^{7}$ (what is the extent of individuals' entitlement to the protection of their person or belongings?). Under a classic constitutional paradigm pertaining to the offline space, the proportionality test is often relied on to adjudicate interferences in the

\footnotetext{
${ }^{4}$ E Carolan and A Spina, «Behavioural Sciences and EU Data Protection Law: Challenges and Opportunities » in A Alemanno and AL Sibony (eds), Nudge and the Law (Oxford: Hart Publishing 2015) 8; F Zuiderveen Borgesius, «Behavioural Sciences and the Regulation of Privacy on the Internet» in A Alemanno and AL Sibony (eds), Nudge and the Law (Oxford: Hart Publishing 2015); L Belli and J Venturini, "Private Ordering and the Rise of Terms of Service as Cyber-Regulation » (2016) 5:4 Internet Policy Review 1-17; T Büthe, «Private Regulation in the Global Economy: A (P)Review » (2010) 12:3 Business and Politics 1-38; D Baron, «Private Ordering on the Internet: The Ebay Community of Traders » (2002) 4:3 Business and Politics 245-74.

${ }^{5}$ L Lessig, Code 2.0. (Basic Books 2006).

${ }^{6}$ See eg C Petersen, V Ulfbeck and O Hansen, «Platforms as Private Governance Systems - the Example of Airbnb " (2018) Nordic Journal of Commercial Law 38-61; M Finck, « Digital Co-Regulation: Designing a Supranational Legal Framework for the Platform Economy" (2018) 43 European Law Review 47-68; B Cannon and H Chung, " A Framework for Designing Co-Regulation Models Well-Adapted to Technology-Facilitated Sharing Economies » (2015) 31 Santa Clara Computer and High Technology LJ 23-96; C Reed, Making Laws for Cyberspace (Oxford: Oxford University Press 2012); D Koukiadis, Reconstituting Internet Normativity. The Role of State, Private Actors, Global Online Community in the Production of Legal Norms (Baden-Baden: Nomos 2015); C Marsden, Internet Co-Regulation: European Law, Regulatory Governance and Legitimacy in Cyberspace (Cambridge: Cambridge University Press 2011).

${ }^{7}$ See eg C de Terwangne and Q Van Enis, L'Europe des droits de l'bomme à l'beure d'Internet (Brussels: Bruylant 2019); J Venturini, L Louzada, M Maciel, N Zingales, K Stylianou, and L Belli, Terms of Service and Human Rights: An Analysis of Online Platform Contracts (Editora Revan, Rio de Janeiro 2016); S Hick, E. Halpin and E. Hoskins, Human Rights and the Internet (Palgrave Macmillan UK 2016); R Fisman, and L Michael, Fixing Discrimination in Online Marketplaces, HBR, no. December 2016; C Geiger, and E Izyumenko, « The Role of Human Rights in Copyright Enforcement Online: Elaborating a Legal Framework for Website Blocking » (2016) 32:1 Am U Int'l L R 43; A Savin, EU Internet Law (Cheltenham: Edward Elgar 2013); J Glaser, and K B Kahn, « Prejudice and Discrimination and the Internet » in Y Amichai-Hamburger (ed), The Social Net. Human Behavior in Cyberspace (Oxford: Oxford University Press 2005) 247-274. For an analysis under Intellectual Property perspective, N Tusikov, Chokepoints: Global Private Regulation on the Internet (Univ of California Press 2016). For an early analysis under freedom of expression, M Siegel, « Hate Speech, Civil Rights, and the Internet: The Jurisdictional and Human Rights Nightmare Comment »(1998-99) 2 Albany Law Journal of Science \& Technology 375-98. For an analysis under non-discrimination, see A Chander, «The Racist Algorithm? » (2017) 115:6 Mich L Rev 1023-45. With regards to online access to justice, E Katsh and O Rabinovich-Einy, Digital Justice: Technology and the Internet of Disputes (New York: Oxford University Press 2017).
} 
rights held by citizens. This paper argues that a transposition of the proportionality test from this usual offline setting to the online world may provide for answers when digital operators are confronted with colliding rights held by platform users or when they wonder whether they should or could interfere with the rights of users. Yet, for this transposition to provide a meaningful solution, the role, scope and limits of the proportionality test need to be better framed and supplemented by an overall digital environment feeding the proportionality test in an appropriate way.

This paper is structured as follows. It first locates sanctions within the conceptual framework of transnational hybrid governance and especially within the "modern public square" (Section 2), before revisiting proportionality, a traditional principle underpinning the balancing of rights and freedoms and the imposition of sanctions (Section 3). It then looks at the practical application of the proportionality test that digital operators need to consider when enforcing sanctions on their platforms (Section 4). In order to go beyond the limits of the proportionality test, this paper then suggests two avenues - one institutional and one community-based to address gaps in the discussions triggered by relying on the proportionality test to address colliding rights on the modern public square (Section 5). Section 6 concludes on further research avenues.

\section{FRAMING COORDINATION OF DIFFERENCES IN THE ONLINE WORLD}

To analyse the tools available to digital operators faced with colliding rights of users in the offline world, we need to proceed in two steps: first, one needs to understand what the digital space is in terms of interactions, ie a modern public square with gate-keepers and umpires, the digital operators, entrusted with specific "warden" functions (2.1); secondly, if we see the digital world as an extension of the offline space, under the form of a modern public square, one needs to consider how the law would label digital operators' interferences with colliding rights if we were in offline space, in particular one needs to examine if these interferences may be called "sanctions". One may then test whether it is possible to extent this label of "sanctions" to the reactions taken by digital operators to coordinate colliding rights in the online world, with all the legal consequences attached to this label (2.2).

\subsection{The modern public square: different voices in a transnational space}

Platform operators illustrate perfectly transnational hybrids: they operate across many jurisdictions, providing services in many countries, with key nodes located in strategically chosen countries in order to enjoy favourable legal rules pertaining to contracts, data, taxation, intellectual property for examples. The platform users are only vaguely aware that Uber processes worldwide payments to drivers (except in the US) through a Dutch company resident of the Bahamas. Similarly, Amazon.co.uk has no permanent establishment in the United Kingdom: it is incorporated in Luxembourg. These average same users are even less aware of the technological infrastructure leading some digital platforms to file taxes for their users in Ecuador or in Estonia when a contract is concluded. These features are key economic components in digital platforms however. Digital platforms play multiple roles however: they enable economic transactions between peers and are also vehicles for social and political interactions or behaviour. They do not only facilitate communication and exchanges; they also control communication between the parties to a transaction and facilitate payment, and thus extract a commission or a fee as a price for their intermediation. ${ }^{8}$

This specific situation entails three main features for digital platforms; they are digitalised, transnational and pluralist. First, digital platforms are digitalised, ie an extension of the offline space into the online world. Hence actions taken by digital platforms may cause significant harm to individuals in the offline space. For instance, when a social media influencer's account or an Uber driver is deactivated, it limits their freedom of expression, but it also prevents them from conducting their professional activity. In the same vein, when Uber deactivates one of its riders' account because of her misconduct, it impacts on her mobility. These offline consequences need to be included in any assessment of the online space. Secondly, digital platforms

${ }^{8}$ D McKee, «The platform economy: natural, neutral, consensual and efficient? » (2017) 8:4 Transnational Legal Theory pp. $455-495$. 
are transnational, ie technological structure facilitating social and economic activity across people and borders or regardless of borders. Thirdly, they are pluralist, ${ }^{9}$ in the sense that users come with different expectations and values when they operate on the digital platforms, some visible to the other users, some not so visible. In particular, digital users harbour different expectations, attitudes and understanding of how to behave. This is not only due to their different cultural and spatial attachments. This is also due to the changed visibility of their actions. Their visibility is increased as the Internet helps reach and put in contact users in an extensive way. Visibility is also modified because when posting or acting on digital platforms, the users may not know to which audience they will become visible (in time and space).

This paper considers that the conjoined effect of these three features of digital platforms lead to the development of a specific space of political, social, economic and technological interactions, a space best encapsulated under the expression of a "modern public square". ${ }^{10}$ This expression reflects that digital platforms constitute an environment where goods, services and data are purchased or exchanged as well as news, opinions, ideas or creative expressions through digital interactions among people from potentially widely different backgrounds and who potentially know each other very well or not at all, who may repeat their interactions in the long term or never again. Relationships and exchanges between users on the modern public square may be conducted with very different strategies in mind. The modern public square cannot expect these relationships and exchanges to be harmonious by themselves. Collisions between rights held by users happen. ${ }^{11}$ Doubts arise about their legal solutions. For instance, what is legally, politically or morally acceptable somewhere may not be elsewhere. Identifying where to look for a legal solution may not be an easy task. Overall, the modern public square has to rely on a certain level of organisation, ${ }^{12}$ to ensure the coordination of exchanges and relationships.

Digital platforms challenge the classical relationships between power, law and territory as developed in classic international public law. They are part of global cross-border phenomena, with colliding public and private bodies claiming authority to organise social relationships and economic exchanges. States adopt laws applying to the whole of society while functional actors such as digital platforms are hyper-specialised (technically and functionally); they accumulate technical and social capital in a limited range of issues. However digital platforms combine extensive powers in their hands (through the combination of hard law and self-regulatory techniques such as the setting of terms of services): in a way, they concentrate quasinormative, quasi-executive and quasi-judicial powers because they both create the applications, networks and things under their control and regulate their functioning. ${ }^{13}$

This leads to two questions when comparing the modern public square and the offline space of economic and political actions. One question pertains to the overall organisation of this modern public square in general. To answer this question one may venture to say that this modern public square is not a mere virtual construction with no supporting structure, underpinning organisation and normativity. This paper suggests that this modern public square, as a concept spanning the online and offline space, needs to be equipped with the necessary systems, institutions and procedures allowing for identifying problematic behaviour threatening its (economic, social or political) integrity and for providing for argumentation and discussion to happen in response to users' behaviour. There should be an accepted reflexive framework for calling actors to accountability, giving them an opportunity to make their case, to be listened to and properly

\footnotetext{
${ }_{9}^{9}$ Cfr M Delmas-Marty, Ordering Pluralism - A Conceptual Framework for Understanding the Transnational Legal World (Oxford: Hart 2009).

10 This notion refers here to these three main features, although there may be other relevant features connected with this notion. These three main features are relevant for analysing sanctions and proportionality as explored within the limits of this paper.

${ }_{11}$ D Harvey, Collisions in the Digital Paradigm: Law and Rule Making in the Internet Age (Oxford/Portland: Bloomsbury Publishing 2017).

12 McKee (above (8)) explains how the "market" is not natural but has required historically structures to ensure that free exchange happens.

${ }^{13}$ L Belli and C Sappa, «The Intermediary Conundrum: Cyber-Regulators, Cyber-Police or Both? » (2017) 8 JIPITEC 183 para 7-8; E Marique and Y Marique, « Sanctions on digital platforms - beyond the public/private divide » (2019) 8:2 Cambridge Journal of International Law (forthcoming).
} 
replied to. ${ }^{14}$ This type of framework would thus be a way to incentivise functional actors, such as digital platforms, to factor in the potential externalities of their decisions in their decision-making processes. ${ }^{15}$

Another question pertains to the role (powers and duties) that digital operators play on this modern public square. Due to the specific positions of digital operators on the modern public square as regulator and controller, this question asks whether digital platforms do have specific duties with regards to its functioning and in particular identifying and addressing problematic behaviour on the modern public square. In the online world, digital platforms are entities entrusted with functions akin to administrative policing, which puts them in charge of securing the general preservation of public order and morality. ${ }^{16}$ There is a need for systems to guarantee the respect of the established rules, and prevent undue inconvenience for the integrity of life in the community. In the offline space, entities entrusted with such functions may be public or private actors, which may lead to distinction between their priorities in discharging their functions. ${ }^{17}$ An increasing amount of empirical and socio-legal research shows that public law requirements, controls and accountability mechanisms are currently extended to private actors. ${ }^{18}$ It is suggested here that digital operators have a duty to take the appropriate measures to ensure the integrity of users' interactions on the modern public square, subject to suitable accountability mechanisms. This duty has been connected to their role of gate-keeper of the platform ${ }^{19}$ or cyber-police. ${ }^{20}$ It will be referred to here as their "warden" function, because digital operators can exclude users from the modern public square as much as they can take a range of measures in relation to behaviours threatening the integrity of the modern public square. We turn to labelling these measures in the following lines.

\subsection{Digital operators' (re)actions in case of colliding rights: sanctions}

What constitutes sanctions has been discussed for centuries. Orbediek provides a good analytical starting point. For him, "a sanction, [...] is any threatened, promised, instituted or declared response on behalf of a group or institution attached to the breach or neglect of a recognized norm, policy, order, law or command done with the implicit or explicit intent of discouraging or preventing any such breach or neglect." ${ }^{21}$ Sanctions bear interconnected features.

Sanctions are such a response, relying on the exercise of power and taken by digital operators towards undesirable behaviour on the modern public square. Sanctions react to a specific problematic situation or behavior defined as such by a socially recognized rule. ${ }^{22}$ Therefore, unintended actions of the platform

14 P Kjaer, «Why justification? The structure of public power in transnational contexts » (2017) (8:1) Transnational Legal Theory 8-21.

${ }^{15}$ G Vilaca, "Transnational legal normativity » in M Sellers and S Kirste (eds), Encyclopedia of the philosophy of law and social policy (Springer 2017)

${ }^{16}$ L Belli and C Sappa, «The Intermediary Conundrum: Cyber-Regulators, Cyber-Police or Both? » (2017) 8 JIPITEC 183 para 18.

${ }^{17}$ In particular, private entities may seek profit maximisation over general well-being ( $c f r$ recurring issues in contracting out of public services in Europe). L Belli and C Sappa, «The Intermediary Conundrum: Cyber-Regulators, CyberPolice or Both? » (2017) 8 JIPITEC 183 para 19.

18 A Benish and J Pelisse, "Private companies and administrative justice » in M Hertogh, R Kirkham, R Thomas and J Tomlinson (eds), Oxford Handbook of Administrative Justice (Oxford: Oxford University Press forthcoming); J Bell, "Judicial Review in the Administrative State» in J de Poorter, E Hirsch Ballin and S Lavrijssen (eds), Judicial Review of Administrative Discretion in the Administrative State (Springer 2019) 3-26; J Freeman, «Extending public law norms through privatization » (2003) 116:5 Harvard Law Review 1285-1352.

${ }_{19}$ M Cian, "Online Platforms as Gatekeepers to the Digital World - a Preliminary Issue on Business Freedom, Competition and the Need for a Special Market Regulation" (2018) Journal of European Consumer and Market Law 20910; R Van Loo, "Rise of the Digital Regulator" (2017) Duke Law Journal 1317.

${ }^{20}$ L Belli and C Sappa, «The Intermediary Conundrum: Cyber-Regulators, Cyber-Police or Both? » (2017) 8 JIPITEC 183.

${ }^{21}$ H Oberdiek, "The Role of Sanctions and Coercion in Understanding Law and Legal Systems » (1976) 21:1 The American Journal of Jurisprudence $71-94$ at 75.

22 Such social recognition can be problematic on digital platforms when it comes to users "accepting terms of services" without reading the fine prints. While platform operators take a formal stance on what constitutes a "recognized rule", they will face the criticism of consumers' associations that users are not aware of the substance of the rule. These associations would thus challenge that platform "can even take such measures". However, the formal approach chosen 
operators, such as accidental exclusions by the algorithm (eg repeated error messages, non-technical recognition of information not included in the system) do not count as sanctions in this respect. This reactive nature of the sanction is important: they constitute a consequence of a behaviour rather than a condition for action. They can be automatized, or not, as a consequence of the behaviour, but cannot be considered a priori, without preliminary users' actions or problematic behaviour.

Although their functions can be discussed, sanctions usually have two main purposes, one negative and one positive. On the negative side, sanctions aim to ban a behavior or an action arising from social relationships and economic exchange. They aim to discourage users from adopting certain problematic behaviors, such as preventing illegal contents and harassment. On a more constructive side, sanctions can be retributive (where the individual needs to "pay back" to the community for the infringement), reparative (where the individual is isolated to place the community back in a state of peace as if the violation had never taken place), ${ }^{23}$ or pedagogic (when they help users to identify, learn and transmit the core values the platform wishes to promote). ${ }^{24}$ For practitioners (and academics), sanctions can thus express how amount digital operators defend certain values over others and counterbalance the marketing narratives with their actual practices. Such approach is indeed defended (with more or less success) by labor lawyers trying to characterize the sanctioning power of Uber and Deliveroo as a supervision and control mechanism giving rise to an employment relationship rather than an independent "partnership" agreement. ${ }^{25}$ Conversely, failure to act against certain behaviors, despite recognizing them as unwanted in terms of services or marketing practices, amount to a policy choice that the underpinning value is not worth enough fighting for.

In the offline world, these actions would fall within the definition of "sanctions", with all the legal consequences attached to that legal qualification, including the availability of a judicial or independent review mechanism. ${ }^{26}$ Principles of review need thus to be established on the modern public square. This paper proposes to examine the principle of proportionality under these new lenses.

\section{A TEST FOR ELUCIDATING THE HUMAN RIGHTS IN CONFLICT IN A MODERN PUBLIC SQUARE}

Once the reactions from digital operators are labelled as a known legal category, that of sanctions, the legal consequences usually attached to this legal category can be investigated further. ${ }^{27}$ Here the requirement of proportionality takes a special role for its principled use in the case of colliding rights (3.1) and for the modalities that have been suggested for this test in the digital space (3.2).

\subsection{Proportionality in principle}

Faced with colliding rights on the online world, such as freedom of expression $v$ s the right to privacy or freedom of expression $v$ s public health policies, ${ }^{28}$ platforms have a range of possible options: from doing nothing and letting users act as they wish to giving priority to specific rights or specifying a clear hierarchy between the rights at stake for instance. There is a preliminary question here: should digital operators interfere with users' interactions at all? It may be argued that any interferences with users' activities on the

by the platform enable lawyers, litigators and practitioners to characterize platform behaviors as sanctions and therefore to find the need for adequate protection as sanction.

${ }^{23} \mathrm{Eg} \mathrm{M}$ van de Kerchove, «Les fonctions de la sanction pénale. Entre droit et philosophie » (2005) 127:7 Informations sociales 22-31, 27-30.

${ }^{24}$ For such an interpretation of Durkheim, see J Feinberg, Doing and Deserving (Princeton: Princeton University Press 1970) 102.

${ }^{25}$ C Wattecamps, A-G Kleczewski and E Marique, « Challenges related to law for the platform economy: A fresh look at some important dichotomies» (2017/3) Reflets et perspectives de la vie économique 57-95, 66-71.

${ }^{26}$ Following that line of reasoning, see $\mathrm{eg}$ SL Kaleda, "The Role of the Principle of Effective Judicial Protection in Relation to Website Blocking Injunctions » (2017) 8 JIPITEC 216 para 35.

${ }^{27}$ Other legal aspects than proportionality, such as legality or procedural guarantees, are not investigated within the limited remit of this paper.

28 See Introduction the examples of 8 chan and Pinterest. 
digital platforms would be akin to censorship. ${ }^{29}$ However, it may be advanced that the general interest of the "modern public square" requires that at least some level of policing and monitoring of users' activities on the platforms is organised. This allows to maintain a good environment for social interactions and exchanges on the digital platforms. The question shifts then from the principle of interference on the modern public square to the modalities of this interference, and especially how digital operators collect the information needed to carry out their minimal desirable monitoring, process it, organise their decisionmaking on their basis and implement it in practice. If one accepts this position, the proportionality test may be a tool to ensure that digital operators follow a reasoning process that can be called for account.

The proportionality test of public action is widely accepted as a way for controlling public power ${ }^{30}$ and sanctions $^{31}{ }^{32}$ This test may be used at different stages of the sanctioning process, ie when setting the normative framework, monitoring compliance, imposing sanctions, implementing them and/or adjudicating between colliding rights in specific or general circumstances; or when reviewing them. Normally, the proportionality test implies that decision-makers should only follow a course of action if 1) their objective is legitimate; 2) their means is necessary to achieve their objective; 3) no means would entail a lighter encroachment of the right at stake; 4 ) the means is proportional (sensu stricto) to the objective to be achieved. The conceptual foundations and modalities for this test are endlessly discussed. ${ }^{33}$

Proportionality has been much criticized for its apparent neutrality. It would allow judges to review administrative actions without imposing their own values and priorities about which course of action is preferable in a specific case. However value judgements may be hidden at each stage of the reasoning process, ${ }^{34}$ at the levels of both administrative and judicial decision-making. This challenges the uniform application and the predictability of the proportionality test. Yet, it is often said that the proportionality test provides a tool for requiring decision-makers to explain their reasoning process. In so doing, the proportionality test helps foster a culture of justification and persuasion. ${ }^{35}$ In order to allay these criticisms, Alexy suggested an abstract "weight formula" assessing the interferences in the rights at stake in a more objective way. ${ }^{36}$ In a modern public square, an additional challenge arises, that of identifying the main actors of this culture of justification and persuasion.

\footnotetext{
${ }^{29}$ Report of the Special Rapporteur on the promotion and protection of the right to freedom of opinion and expression, 16 May 2011, Human Rights Council, 17th session, para 40-43.

${ }^{30}$ For an attempt to reconcile the American and the European approaches to balancing rights: K-H Ladeur, «A critique of balancing and the principle of proportionality in constitutional law - a case for 'impersonal rights'? 》 (2016) 7:2 Transnational legal theory 228-256.

${ }^{31} \mathrm{Eg}$ for administrative sanctions: C.E. fr., 19 mai 1933, Benjamin. A comment is available on the French Conseil d'Etat's website: http://www.conseil-etat.fr/Decisions-Avis-Publications/Decisions/Les-decisions-les-plusimportantes-du-Conseil-d-Etat/19-mai-1933-Benjamin.; for discussions in relation to criminal sanctions: eg A von Hirsch, "Proportionality in the philosophy of punishment » (1992) 16 Crime and Justice 55-98; J Deigh, "Punishment and proportionality » (2014) 33:3 Criminal Justice Ethics 185-199; J Deigh, « Punishment and proportionality: Part 2 » (2016) 35:1 Criminal Justice Ethics 21-38.

32 A Stone Sweet and J Mathews, «Proportionality balancing and global constitutionalism » (2008) 47 Colum J Transnat'l L 72-164.

${ }^{33}$ Eg: F Urbina, « Is it really that easy - A critique of proportionality and "balancing" as reasoning » (2014) 27:1 Canadian Journal of Law and Jurisprudence 167-192; M Klatt and M Meister, « Proportionality - A benefit to human rights - Remarks on the I-Con controversy » (2012) 10 Int'l J Const L 687-708.

${ }^{34}$ Eg: S Greer, "'Balancing' and the European Court of Human Rights: A Contribution to the Habermas-Alexy Debate » (2004) 63:2 Cambridge Law Journal 412-434.

${ }^{35}$ D Dyzenhaus, «Proportionality and deference in a culture of justification » in G Huscroft, B Miller and G Weber (eds), Proportionality and the rule of law - Rights, Justification, Reasoning (Cambridge: Cambridge University Press 2014) 234258.

36 R Alexy, «The construction of constitutional rights » (2012) 91:3 Revue française de droit constitutionnel 465-477; R Alexy, « Proportionality, constitutional law, and sub-constitutional law: A reply to Aharon Barak» (2018) 16:3 I•CON 871-879.
} 


\subsection{A specific proportionality test for the digital space: The internet balancing formula ${ }^{37}$}

In the context of colliding rights in the online world, Susi builds on Alexy's weight formula to devise in concrete and practical terms a test that platform operators could use when making decisions pertaining to response to problematic behaviors and interactions happening on their platforms. While Alexy's balancing formula is expressed at a high level of abstraction to balance the intensity of interferences between human rights, ${ }^{38}$ Susi gives an operational and concrete translation of the formula in the case of conflicts between the right to privacy and freedom of expression. His approach is best summarized as follows.

The first step of the reasoning is to exclude any balancing in case of hate speech, as hate speech should always be banned from digital platforms. The second step is to calculate the "value" of the right to privacy, which is the addition of the following factors: the vulnerability of the individual due to internet technologies, the interference in privacy (calculated in taking the perspective from an neutral onlooker), and the element of time with time passing being assumed to be a decreasing factor in terms of interference. ${ }^{39}$ The third step in the reasoning pertains to the calculation of the numerical value of the freedom of expression. This is based on the addition of three elements:

1) the level of public interest in the matter (ie: minor public interest is public interest measured in terms of the local community affected by the matter; medium public interest refers to cases when the larger community is affected but with no immediate direct impact on the lives of the majority; and significant public interest to cases when matters affect the entire nation or have a direct effect upon the lives of the majority);

2) the determination as to whether the information concerns a public figure;

3) the ways in which information has been obtained (either legally or not, either morally or not). ${ }^{40}$

In addition, on each side of the formula, a further factor needs to be added, which Susi calls "empathy". The exact meaning of this concept is not clear, but its function is to ensure that human agency has to intervene in some cases at least, namely when there is a break even between the two sides of the equation and when moral reasons command it. ${ }^{41}$ Finally, Susi reserves a specific treatment to cases where divulgation of the information trumps privacy due to its contribution to historical truth. ${ }^{42}$

Susi stresses that this formula should give a rational answer to cases where the right to privacy and the freedom of expression collide, a formula that would allow anybody, the "citizen journalist" included, to decide if an information should or could be published on a digital platform. ${ }^{43}$ Anyone - even without legal training - would be able to use it. ${ }^{44}$ This would thus prevent abuse and censorship from digital platforms in refusing to publish online information. ${ }^{45} \mathrm{~A}$ higher degree of transparency would indeed be gained. The formula would provide standards to carry out the assessment and the argumentation behind the decision.

\section{OPERATIONALIZING PROPORTIONALITY IN CASE OF "SANCTIONS": TESTING LIMITS}

In developing their platform architecture, policies and implementation tools, digital operators make a range of choices pertaining to the best strategy to address colliding rights on an on-going basis. In their search for finding a technique that could be accommodated with their technologies, they might be interested to

37 M Susi, «The Internet balancing formula » (2019) 25 European Law Journal 198-212.

38 R Alexy, « Mart Susi's internet balancing formula » (2019) 25 European Law Journal 213-220.

39 Susi above (37) 205.

40 Susi above (37) 205-207.

41 Susi above (37) 207.

42 Susi above (37) 208.

43 Susi above (37) 199.

${ }^{44}$ Susi above (37) 204.

45 This discussion becomes especially relevant when examining the current European Union reforms on copyright in the Digital Single Market (Directive (EU) 2019/790). This reform might indeed change the current scope of online freedom of speech and other human rights. It will also shift the liability standards for digital operators' actions and thus alter their willingness to commit money in compliance costs. This directive is an opportunity for digital operators to improve their review procedures in order to limit their exposure to liability in the face of undue removal of content. 
turn to the internet balancing formula. If this approach may be a positive addition in their toolkit, there are however areas where caution is required (4.1). Finding means for supplementing the internet balancing formula might be a way forward. Here a more nuanced understanding of the reactions taken by digital operators is offered to distinguish cases where a proportionality test may be used from cases where this may be less the case (4.2).

\subsection{Potential and challenges to the internet balancing formula}

Susi's formula translates the proportionality test into a duty for digital platforms to ensure that their reactions are tailored to each of their users, according to the (relevant) data available to the platform in question following a balancing test between the right to privacy and freedom of expression. ${ }^{46}$ As this approach is appealing to regulate users' behaviours on platforms, it deserves further attention. Its operationalisation faces challenges even if taken on its own terms. As Susi calls for further empirical and philosophical discussions, this paper asserts that a strength of the internet balancing formula is to launch an argumentative and discursive process on the balancing of colliding rights on the modern public square by private actors such as digital platforms. One key issue is however who will be active contributors to this process. Although Susi invites "citizens journalists" and lay people to use the formula and fine-tune it, such a formula is more likely to offer a reflexive framework and argumentative scheme for the use of an epistemic community, made up of digital operators in the first place, some key users, and maybe some social groups especially equipped for this role: ${ }^{47}$ using the formula will indeed require a range of data and skills (including investigation and research skills), especially as some of this data will not be available online. Indeed, if we accept the interactions between the online and the offline worlds, some of the interferences will take place in the offline world, and it is not clear how the information about it will be captured by the Internet (more importantly even, whether it should be captured by the internet in the first place). In addition, using the formula will require a good knowledge of the law and the case law across various jurisdictions, a good grasp of the empirical reality 48 and access to a range of statistical tools about the ways in which platforms operate (their market, audience, countries of operations, specific groups or objectives). Here a technical support will be needed for fostering the concrete use of the formula.

In addition to questions related to the intended users of the internet balancing formula, one may argue whether human rights are ever quantifiable as a matter of principle or about the nitty-gritty aspects of the formula, ${ }^{49}$ but suffice here to mention four general challenges for operationalizing the formula: values; human factors; individual dimension and argumentative space for using the formula. In a way all these challenges turn around one key question: the neutrality of the judgement exercised by the entity operating the formula. This neutrality is not guaranteed. The formula rests on a series of normative choices which could be contested or further argued about in order to test it.

Firstly, the internet balancing formula has two major limits factored into it: first, hate speech is always banned, so that the formula does not apply when hate speech has been identified; secondly, historical truth can never be suppressed, so that the formula is not relevant either in that case. If one can fully agree with these two limits, they are more complicated in practice. Does hate speech have a universal definition? What is historical truth and how is it supposed to be ascertained? What if different groups have different claims about what constitutes historical truth? Is it really the function of digital operators to adjudicate this? In addition, these two limits assume minimal values that cannot be undermined by digital platforms on the modern public square. This leads to questioning whether these values are the only relevant ones or whether

\footnotetext{
46 On the individual tailoring of decisions by algorithms, see for instance E Marique and A Strowel, « Gouverner par la loi ou les algorithmes: de la norme générale de comportement au guidage rapproché des conduites » (2017) 10 Dalloz IP/IT 517-521.

47 See below Section 5.2.

${ }^{48}$ Susi mentions the need to base the formula on empirical experience, but the methods, project designs and the ways in which the findings would feed the formula are not explained (Susi above (37) 204).

49 Professor Alexy flagged up some problems in his answer (R Alexy, « Mart Susi's internet balancing formula » (2019) 25 European Law Journal 213-220).
} 
other values need to be included in a form of minimal core, a kind of "rule of law" for ensuring the integrity of the modern public square, and how they could be identified.

Secondly, the internet balancing formula seeks to recognise the human dimension of the modern public square, through the factors of empathy and internet vulnerability. This approach may be a way to address a subjective assessment of colliding rights by digital operators. There are problems here. In practice, it is difficult to justify why internet vulnerability is given a constant value of " 1 " in the formula and why empathy is given the same value in the two sides of the formula. On the one hand, the constant value " 1 " allocated to internet vulnerability in the formula gives more weight to the right to privacy compared to freedom of expression while different users or individuals may be more or less vulnerable to such exposure. ${ }^{50}$ On the other hand, empathy is supposed to be used in the formula when moral grounds justify it. Yet, managing colliding rights will nearly always have a moral dimension of some kind, which renders unclear whether it is supposed to be included across the board or in borderline cases that remain to be identified.

Thirdly, the internet balancing formula is geared to address conflicts between the right to privacy and freedom of expression, and their individual variations. Yet, other rights - including collective rights and freedoms - may also have to be included in any balancing exercise as well as the longer and shorter terms effects of these balancing exercises. ${ }^{51}$ It is not clear how the internet balancing formula can be expanded to take these aspects into account.

Finally, that the internet balancing formula contributes to confidence and transparency on the modern public square platforms needs to be acknowledged as important. Two points can be made here. The first one relates to the discursive and argumentative framework within which proportionality is used by judges for adjudicating offline colliding rights. Judges are acting within specific argumentative constraints: they need to convince a range of players that their decisions are the right ones. These constraints may work in different ways depending on the judiciaries, but they usually have two key features. Firstly, judges usually work within tight procedural constraints where both parties have the opportunity to make their case, to be heard, to be listened to and to be responded to, which are important components for recognising the human dignity of the players and to respect them. ${ }^{52}$ Secondly, judges normally work within a constitutional context where the legislature can react to judicial decisions if they disagree with them. This step may or may not be activated, or only activated in marginal cases, but it does exist. This has two key consequences. The first consequence is that judges often act incrementally, often steeped in pragmatism. ${ }^{33}$ The second consequence is that judges work within a community of legal professionals, dialoging, resisting and communicating with them. These key features of the discursive and argumentative framework underpinning the use of proportionality in offline conflicts of rights are not guaranteed in the case of the internet balancing formula. At least Susi does not suggest ways in which they would be replicated. One may be forgiven to think that the formula is meant to be included in an algorithm of some kind and that contestations and challenges may arise, although Susi does not spell out the grounds, space, processes or institutions which would host these challenges. It is thus not clear whether digital platforms think of themselves as being held to convince peers and institutional actors (regulators? investors? stakeholders?) and according to which criteria (economic performance? corporate social responsibility in some form? something else?).

Overall, the modern public square does not include an institutional or procedural framework similar to what exists in the offline world for judges. In particular, the modern public square - with its key features of being digitalized, transnational and pluralistic - comes with a highly disaggregated audience. If and when digital operators want to rely on a proportionality test such as the internet balancing formula (or a possible variation thereof) to exercise their warden functions, the proportionality test may be used as a focal point of attention, drawing the interests of users likely to be affected by its use, but the whole modern public square will need to be equipped with further structures, institutions and processes so as to ensure that the

\footnotetext{
${ }^{50}$ Alexy above (36) 216-17.

51 We cannot agree with the assumption made by Prof. Susi that the passing of time always decreases the interferences with rights.

$52 \mathrm{~J}$ Waldron, «The rule of law and the importance of procedure » (2011) 50 Nomos, Getting to the rule of law, 3-31.

53 We leave aside here the discussions about judicial activism and "gouvernement des juges", although this very discussion illustrates that judges need to be persuasive in their judgments.
} 
components of the formula, its outcomes and modalities are effectively subject to scrutiny, discussions and accountability. In this developmental process, it may be important to fine-tune the cases where a proportionality test carried out by digital operators may be relevant. At an abstract general, a proportionality test can happen at four stages or moments: when a norm identifying a problematic behaviour is set (with the principle and its consequences), when a decision is taken in relation to a concrete problematic behaviour, when the specific reaction to this concrete problematic behaviour is chosen, and when an independent review is carried out into this reaction. Here, distinguishing between types of reactions by digital operators about colliding rights can be made can help better understand when digital operators may carry out a proportionality test for ensuring the integrity on the modern public square. A typology of these reactions is offered in the next sub-section.

\subsection{Typology of sanctions in the modern public square}

In the online world, digital platforms sanctioning processes can be broken down into four main types: 1) platforms acting on behalf of public bodies to sanction illegal behaviors (under EU/international or domestic law); 2) platforms using a discretionary power to implement policies or legal obligations adopted by public bodies; 3) platform operators imposing sanctions for behaviors they have identified themselves as undesirable; and 4) sanctions imposed following a quasi-judicial process organized by platforms to adjudicate between users.

In the first category of sanctions, operators may have to take action to take down content on the platforms, so as to avoid becoming liable themselves for hosting or curating illegal content. Good illustrations of this can be found in the secondary liability system protecting intellectual property rights ${ }^{54}$ or in the famous Yahoo! case, where Yaboo! had to restrict access to French users on the part of its platform where nazi memorabilia were put to auction, so as to comply with French law. ${ }^{55}$ In this case, platforms seem to act as delegatees or arms of the state and public bodies: they are in a position to take the necessary actions to ensure that legal obligations or interdictions are complied with. Here a private actor (the operator) extends the reach of public bodies onto the platforms. The private assists and enhances/strengthens the capability (action) of public bodies at a practical/material level.

In this first case, a statute clearly puts an obligation or a duty on digital operators ${ }^{56}$ or a judgment enjoins them to comply with the law. ${ }^{57}$ In such scenario where a legal duty to act (by statute or by court order) is clearly established, the platform operator does not have to make any proportionality assessment with regards to the principle of an interference in users' rights nor in its application. It merely has to assess whether the response triggered by the violation is proportionate to the infringement (to the extent that the expected response is not dictated by statute or court decisions). For instance, hate speech (or conversely, historic truth) is ipso facto outside of the scope of the Susi's formula. In such a scenario, states take the principled decision to forbid (or conversely, authorize) the publication of such content. Here, states assess the proportionality, not the digital operators who have no scope left to exercise a proportionality test.

In the second category of sanctions ("co-regulation"), the digital operator acts on behalf of public bodies but the exact link and its legal nature can be difficult to pin down. The digital operator may seem in a position where it can easily implement legal obligations and enforce them on the platforms. Yet, in practice, legal obligations do not get implemented in a void, through a magic wand or in a mechanical fashion. Some norms provide a large leeway for the operators to decide whether to respond or not to the violation of some legal duties and the extent of this violation. Digital operators have to develop processes and techniques to detect infringements and to decide what to do with them. For instance, Facebook hired teams of content moderators/reviewers in Germany to ensure that users acting on its platform comply with the

${ }^{54}$ R Drath, « Hotfile, Megaupload, and the Future of Copyright on the Internet: What Can Cyberlockers Tell Us About DMCA Reform » (2012) 12 J Marshall Rev Intell Prop L 205.

55 Paris Trial court, Ligue Contre le Racisme et l'Antisémitismev Yahoo!, 20 November 2000; Yahoo! Inc., v La Ligue Contre Le Racisme et l'Antisémitisme, 379 F 3d 1120 (9th Ct, 23 August 2004).

${ }^{56}$ See for instance J Riordan, The Liability of Internet Intermediaries (Oxford: Oxford University Press 2016) 114-16

${ }^{57}$ Paris Trial court, Ligue Contre le Racisme et l'Antisémitisme v Yahoo!, 20 November 2000; Yahoo! Inc., v La Ligue Contre Le Racisme et l'Antisémitisme, 379 F 3d 1120 (9 ${ }^{\text {th }}$ Ct, 23 August 2004). 
German Network Enforcement Law and German criminal law. But this team has several options in front of them when examining content. Removal of certain sets of content uploaded is not the only possible response. Other solutions are available for platforms, such as retrograding the rank of content, making warnings or disclaimers about the content (as for website allowing classified ads for escort services or pornographic video sharing) or restricting comments (as online news website aware that some comments might go quickly off-topic because of political sensitivity). The platform, as an actor of the modern public square, is required to examine the proportionality of the reaction (the sanction) to the user's actions (users' misbehavior). This means that this passing of compliance monitoring functions on digital operators has a transaction cost for them. This also means that this implementation system can be flawed in many ways maybe just because the scope of the obligations may be difficult to ascertain, because there may be conflicting obligations ( $e g$ with different jurisdictions claiming the right to regulate some actions) or because the operators decide to be over-inclusive in their systems in order to avoid their own liability.

In the third category of sanctions ("self-regulation"), digital operators develop their own ordering and discipline: they may decide which actions and behaviors are allowed on digital platforms, banning other actions as undesirable. ${ }^{58}$ Digital operators have here a wide scope to exercise a two-prong proportionality test, with regards first the principle of interference and secondly the modalities of the sanction.

At the level of principle, digital operators, acting in their capacity of warden on the modern public square, 59 decide what the code of conduct and the social norms on the platforms are. They police behavior so as to ensure a specific ethos on the modern public square. An illustration of this kind of self-regulation is the decision taken by Facebook to ban nudes on pictures. ${ }^{60}$ Here, digital operators develop their own sovereign spheres of power: they decide the norms that have to be complied with, the ways in which they want to monitor compliance and their enforcement. This may all seem to be the case of private operators exercising private powers under contractual agreement. Yet, platform power imbalance means users become part of the contractual ordering through adhesion, which is more like a social organization where the rules of the games have the power to include and exclude users, and which may discipline the membership against their will. In that case, the essence of this process seems to be close to that of a sovereign's authority, not based on the freedom of will core to private entities. In addition, the policing of the platform is deemed, under economic theories, to be done "in the public interest", as to attract as many users as it can. ${ }^{61}$ The organ may be private in its legal form, but the very essence of the relationship is public. ${ }^{62}$ In this warden function, digital operators may be in a position to apply the internet balancing formula to its fullest extent (taking into accounts all the caveat discussed in Section 4.1).

At the level of modalities, platform operators select the most appropriate sanction amongst a large scale of possible options following the proportionality test, on the same model as already developed in the discussion on the second category of sanctions.

In the fourth category of sanctions, digital operators do not act on their own initiative or on behalf of public bodies: they act as judges in adjudicating disputes between users on the platforms. Operators then develop dispute resolution procedures which may take a range of modalities, some being mostly automated, some

${ }^{58}$ L Belli and J Venturini, « Private Ordering and the Rise of Terms of Service as Cyber-Regulation » (2016) 5:4 Internet Policy Review 1-17.

59 See above Section 2.1.

60 Facebook Community Standards, '12. Violence and Graphic Content' $<$ https://www.facebook.com/communitystandards/graphic_violence $\geq$; see also Facebook Community Standards, '13. Violence and graphic content' < https://perma.cc/KZ39-CZUA > both sources accessed 22 July 2019.

${ }^{61}$ Przemyslaw J Palka, "Terms of Service are not Contracts - Beyond Contract Law in the Regulation of Online Platforms » in S Grundmann (ed) European Contract Law in the Digital Age, vol 3 (European Contract Law in the Digital Age, Intersentia 2018) 136-61. Add E Marique and Y Marique, "Sanctions on digital platforms - beyond the public/private divide », (2019) 8:2 Cambridge Journal of International Law (forthcoming). Even platforms identifying a niche (such as hate-propagating platforms such as 4chan and 8chan) try to increase the number users within the defined niche, eliminating or decreasing the reasons for users to access competitor websites.

${ }^{62}$ E Marique and Y Marique, «Beyond the Public and Private Divide on Digital Platforms? Revisiting Power Relationships » in E Bani, E Rutkowska-Tomaszewska and B Pachuca-Smulska (eds), Public Law and the Challenges of New Technologies and Digital Markets (CH Beck 2019 forthcoming). 
relying on human judgment. ${ }^{63}$ They need to design a system able to cope with a large number of issues and yet give users confidence that it is impartial / not too much biased. As the dispute is of a private nature (between two users), the adjudicating platform has little leeway to examine proportionality because the dispute is in the hand of the parties and respond to framework of relationships under private law, which solve most issues. If any difficulties arise, the proportionality test may be used as a default option, would one of the three first sets of circumstances described above emerge.

\section{Plugging gAPS IN THE PROPORTIONALITY TEST: TOWARDS MORE SUBSIDIARITY?}

The previous sections point that digital operators may use the proportionality test in a series of cases when they police undesirable behaviours in the modern public square; yet, there reactions (or lack of reactions) have to be called to account. Here, we see that the proportionality test calls for some kind a justificatory structure to be developed. Such accountability may be grounded in a subsidiarity principle for borderline cases. This section explores institutional mechanisms to support such an accountability. On the one hand, this paper suggests that judicial control should complement the application of the proportionality test by digital platforms (5.1). On the other hand, epistemic communities should develop the argumentative framework to adapt it to the necessities of the evolution of digital operators' business models (5.2).

\subsection{Proportionality test in reviewing sanctions}

Digital platforms sanctioning process can go wrong. From abusive content removal to the lack of removal of hate speech through the undue automatic imposition of penalties ${ }^{64}$ or fines ${ }^{65}$, the sanctioning process is subject to errors and mistakes. Users who feel betrayed by the digital operators, suffer losses or want to obtain a remedy against these decisions could consider several legal avenues: breach of contract and extracontractual liability are at the core of the discussions. Contractual claims are often unfit to respond to user's need because of the large discretion attributed to platform operators in the terms of use. Extracontractual claim raise similarly issues in terms of legal base for establishing a ground of liability. Because of the cost and the inappropriate character of these responses, other options need to be reviewed. Self-regulatory industry-wide review bodies have been considered, ${ }^{66}$ but they have been found to be failing, so that they cannot not be relied on too heavily. ${ }^{67}$ Facing the hurdles of these three first avenues, this paper proposes to consider independent review procedures for decisions undertaken by digital platforms on the model of what happens in administrative law, a legal field that developed techniques to control power. In particular, the Global Administrative Law scholarship recognizes that private bodies carrying out regulatory functions at a transnational level should be submitted to control similar to these existing in administrative law. Indeed, "due to the lack of international public institutions, they often have great [..] power and importance". ${ }^{68}$

Independent review should thus take place, to control digital operators' decision, and if needed to overturn/quash them and grant adequate compensation to users. This idea could, at first sight, seem far-

${ }^{63}$ See C Rule, «Designing a Global Online Dispute Resolution System: Lessons Learned from eBay» (2017) 13:2 U St Thomas LJ 354-364. Compare with Aide Youtube, "Qu'est-ce Qu'une Revendication Content ID? 》 $<$ https://support.google.com/youtube/answer/6013276> (FR) accessed 22 July 2019.

${ }^{64} \mathrm{Eg}$ financial gains from a video posted can be reoriented to other users, despite the video amounting to original content.

${ }^{65} \mathrm{Eg}$ penalties for misbehaving during a ride-sharing, for instance dirtying the car typically include the cost of cleaning the car but also a compensation for the driver who will not be able to take passengers during the time of cleaning as well as some incentive to prevent this behavior to take place again in the future.

${ }^{66} \mathrm{Eg}$ Report of the Special Rapporteur on the promotion and protection of the right to freedom of opinion and expression, 6 April 2018, Human Rights Council, 38 th session, at 58.

${ }^{67} \mathrm{See} e \mathrm{ghttps}$ // /ec.europa.eu/digital-single-market/en/news/second-monthly-intermediate-results-eu-code-practiceagainst-disinformation; https://ec.europa.eu/digital-single-market/en/news/fourth-intermediate-results-eu-codepractice-against-disinformation. See also T Schulz, "Does Online Dispute Resolution Need Governmental Intervention? The Case for Architectures of Control and Trust» (2004) 6:1 North Carolina Journal of Law \& Technology 71-106.

${ }^{68}$ B Kingsbury, N Krisch and R B Stewart, «The Emergence of Global Administrative Law » (2005) 68 Law and Contemp Probs 15, 23. Add D Oliver, Common V alues and the Public-Private Divide (Cambridge: Cambridge University Press, 1999) also advocated controlling private powers on the model of controls existing for public powers. 
fetched. However, in practice, such administrative review already exists. Public authorities already review and sanction companies (mis)behaviors. This control goes indeed together with all the rights and duties attached to decision-making by public authorities. Data protection agencies can receive complaint with regards to inappropriate data practice in relation to users' data or inadequate privacy policies ${ }^{69}$; competition law authorities can review business decisions; the English CMA can receive consumers' complaints on platform handling of users; ${ }^{70}$ in the United States, the FCC also has similar powers. ${ }^{71}$ As it stands, thus, this administrative review is not centralized, either in term of territorial-jurisdiction or in term of substancematter. It is diffuse across a number of review bodies.

While judicial review under contractual standard may amount to a strict interpretation of the (breached) duties, extracontractual and administrative reviews are about controlling the powers and the abuses of platforms in their decision making. Additionally, while contractual and extracontractual claims do not have a recognized standard of proportionality review, judicial review of power has developed techniques to carry out a proportionality test. Indeed, amongst other principles applicable to such organizations, such as participation, transparency and reasoned decisions, the Global Administrative Law establishes the necessity for independent or judicial review. Standards considered include the respect for legitimate expectations, means-end rationality, avoidance of unnecessarily restrictive means but also significantly proportionality. ${ }^{72}$ It is therefore possible that, in practice and subject to peculiarities of domestic legal systems, digital operators' power could be included in the existing administrative review process.

In practice, the independent reviewer needs to assess whether the principles of interference, the principle of a sanction and its casuistic modalities is proportional will be the usual proportionality test, as currently developed in the legal scholarship. While Susi's formula would constitute an element to be considered, parties could advance a series of other arguments. If this proposal of independent review becomes ever part of positive law at a large scale/global level, this new set of case-law will also have to be integrated in the platform operators decision-making process. This will hopefully feed a virtuous loop in order to improve the proportionality test for a modern public square.

\subsection{Proportionality test in epistemic communities}

While the paper has outlined the assessment of proportionality in a modern public square by lawmakers, digital operators and independent reviewers, this principle needs to evolve and be discussed in order to ensure its evolution and uniform use. Epistemic communities should develop around the argumentative framework to adapt the proportionality to the necessities of the evolution of digital operators' business models. ${ }^{73}$ As already pointed in Section 5.1, only key users will be equipped with the skills, knowledge, data and tools to operate the formula.

Therefore, to ensure full accountability of digital platform operators, and of their users, a community of "proportionalists" need to emerge. Such community would establish regular, public forums where data available on the (1) forms of interferences and behaviors prohibited, (2) modalities of sanctions, (3) complaints by users and (4) the result of the review process would be shared by the different actors. Interpretation of these results would be subject to discussions, as well as means to improve the existing assessment.

Publicity of these discussions is absolutely necessary. Indeed, the proportionality test as currently framed lack an important component: the public interest factor. While the exclusion for "historic truth" amounts

\footnotetext{
69 See eg in France, Commission national de l'informatique et des libertés Délibération n ${ }^{\circ}$ SAN-2018-011 du 19 décembre 2018 prononçant une sanction pécuniaire à l'encontre de la société Uber France SAS (available on the official website : legifrance).

${ }^{70}$ See $e g$ https://www.gov.uk/cma-cases/online-travel-agents-monitoring-of-pricing-practices .

${ }^{71}$ See $e g$ https://consumercomplaints.fcc.gov/hc/en-us .

${ }_{72}$ B Kingsbury, N Krisch and R B Stewart, «The Emergence of Global Administrative Law » (2005) 68 Law and Contemp Probs 15 at 38-41.

${ }^{73} \mathrm{~S}$ Quack, « Expertise and authority in transnational governance » in R Cotterrell and M del Mar (eds), Authority in Transnational Legal Theory - Theorising Across Disciplines (Cheltenham: Edward Elgar 2016) 361-386.
} 
to one form of public interest, the assessment as proposed under the Internet balancing formula is an individualist approach, with little space for collective, social and cultural rights. This leads to asking the question whether one needs to understand conflicts on platforms from the perspective of balancing rights, freedoms and interests at the level of the beneficiaries (adopting then a subjective approach) or of balancing norms at the point of their sources and authors (adopting then a more objective approach). The contribution of a pluralistic approach may be to accept that these two approaches do not exclude each other automatically, but that a method to coordinate them (at an aggregate level) may offer a way forward. Indeed, power on individuals stands at the interface between these two questions.

In addition, publicity is required to go against the private ordering powers that platform operators enjoy and would limit their discretion, facilitate the functioning of a modern public square, akin to an assembly where groups in their diversity/pluralism can be express their opinions and be heard.

Last but not least, such discussion would ensure the credibility of the proportionality assessment, and its openness to criticism and feedback. The methodology could therefore be refined after discussions with NGOs as well as with professional organizations (eg ethics boards for web developers ${ }^{74}$ ). The discussions would also be an opportunity to educate users and make them learn discursivity and alterity, and to accept differences.

\section{CONCLUSION}

This paper asked how digital operators could manage colliding rights on the modern public square. Suggesting that digital operators have special duties to maintain the integrity and social order as warden of this modern public square, this paper argues that reactions from digital operators towards undesirable behaviours threatening the proper functioning of the community can be labelled as "sanctions". In choosing the principles and the modalities of their reactions, digital operators may rely on a proportionality test when exercising their discretion.

So in the case of 4chan, the digital operators ruled out harassment, hate speech and similar in order to protect users and third parties. Their banning of some abusive behaviours constitutes a reaction showing the core priorities to the platform, ie a strict commitment to comply with the legal framework and to avoid any legal liability. As a by effect, this reaction restored social peace within the community of users. In reaction to this limitation in free speech, a break way group left 4chan to set up 8chan. 8chan's policy was to guarantee freedom of expression as radically as possible. This led eventually to the platform shutdown. These illustrations are extreme: the proportionality test has been exercised in neither cases. However, they show the possible scope and opportunities for a proportionality test. In order to avoid situations as critical, digital operators have interests to adopt moderating techniques, ie to balance colliding values and rights with a proportionality test. However, the long-term sustainability of such a strategy relies on developing a relevant and shared justificatory framework.

Digital platforms should indeed be accountable for their reactions to undesirable behaviours and for breaching their commitments. However, they should keep a certain level of discretion in exercising their warden functions on the modern public square. This rather liberal approach does not exclude that the functioning of the proportionality test to assess sanctions generates ethical behavioural norms for fostering diversity and integrity in the modern public square.

Overall, the use of the proportionality test to assess sanctions on the modern public square should benefit from further analysis into its contribution to the rule of law and to discussions into issues related to global justice on the modern public square.

\footnotetext{
${ }^{74}$ I Sample, "Maths and tech specialists need Hippocratic oath, says academic » The Guardian, London, 16 August 2019 (available at https://www.theguardian.com/science/2019/aug/16/mathematicians-need-doctor-stylehippocratic-oath-says-academic-hannah-fry).
} 


\section{Author bio's}

Enguerrand Marique is a $\mathrm{PhD}$ candidate at the CRIDES (Center for business law) at the UCLouvain School of Law. His doctoral research focuses on the legal tools to build trust in the digital platform economy. His project analyses the legal protections in the management of identification and e-reputation and big data under both private and public law scholarship. Enguerrand was a guest editor for a special issue of the Revue Internationale de Droit Economique on the regulation of digital platforms (publication: September 2019). His main interests pertain to taxation, intellectual property as well as the regulation of algorithms, including in relation with robots. He holds law degrees from the UCLouvain and the University of California at Davis.

Yseult Marique is Senior Lecturer at the University of Essex (UK) and research associate at the FÖV Speyer (Germany). She is the author of Public private partnerships and the law (Edward Elgar 2014) and the coeditor of Access to Justice: Beyond the Policies and Politics of Austerity (with E Palmer, T Cornford, and A Guinchard) (Bloomsbury 2016). Her main research interests focus on the rule of law and its practical implementation in relation to issues of access to limited resources in Western societies (e.g. access to justice, to energy, to public services, to administrative documents, to public participation etc.) and more generally on administrative enforcement and ethics of care in pluralistic Western societies both today and in the past. She holds a law degree from the Universite libre de Bruxelles (ULB) and from the Vrije Universiteit Brussels (VUB) and a $\mathrm{PhD}$ from Cambridge University.

\section{Acknowledgements}

This paper builds on comments and discussions following a presentation made at the $8^{\text {th }}$ Annual Conference of International Law, Cambridge (20-21 March 2019). We would like to thank for their generous comments offered by Professor Benedict Kingsbury, Thomas Streinz, and the two anonymous referees of this special number for their detailed comments, which have opened new avenues for reflection in our work.

\section{Reference list}

R Alexy, « Mart Susi’s internet balancing formula » (2019) 25 European Law Journal 213-220

R Alexy, «Proportionality, constitutional law, and sub-constitutional law: A reply to Aharon Barak » (2018) 16:3 $\mathrm{I} \cdot$ CON 871-879

R Alexy, «The construction of constitutional rights » (2012) 91:3 Revue française de droit constitutionnel 465-477

D Baron, « Private Ordering on the Internet: The Ebay Community of Traders » (2002) 4:3 Business and Politics 24574

J Bell, "Judicial Review in the Administrative State » in J de Poorter, E Hirsch Ballin and S Lavrijssen (eds), Judicial Review of Administrative Discretion in the Administrative State (Springer 2019) 3-26

L Belli and C Sappa, «The Intermediary Conundrum: Cyber-Regulators, Cyber-Police or Both? » (2017) 8 JIPITEC 183

L Belli and J Venturini, « Private Ordering and the Rise of Terms of Service as Cyber-Regulation » (2016) 5:4 Internet Policy Review 1-17

A Benish and J Pelisse, «Private companies and administrative justice » in M Hertogh, R Kirkham, R Thomas and J Tomlinson (eds) Oxford Handbook of Administrative Justice (Oxford: Oxford University Press forthcoming 2021)

R Botsman, Who can you trust?: how technology brought us together-and why it could drive us apart (London: Penguin 2017)

T Büthe, « Private Regulation in the Global Economy: A (P)Review » (2010) 12:3 Business and Politics 1-38

B Cannon and H Chung, «A Framework for Designing Co-Regulation Models Well-Adapted to TechnologyFacilitated Sharing Economies » (2015) 31 Santa Clara Computer and High Technology LJ 23-96; 
E Carolan and A Spina, « Behavioural Sciences and EU Data Protection Law: Challenges and Opportunities » in A Alemanno and AL Sibony (eds), Nudge and the Law (Oxford: Hart Publishing 2015) 8

A Chander, « The Racist Algorithm?” (2017) 115:6 Mich L Rev 1023-45

M Cian, « Online Platforms as Gatekeepers to the Digital World - A Preliminary Issue on Business Freedom, Competition and the Need for a Special Market Regulation » (2018) Journal of European Consumer and Market Law 20910

Conseil d'Etat français, 19 mai 1933, Benjamin

Couderc and Hachette Filipacchi associés v France [GC], 40454/07 (ECtHR 10 November 2015)

Cour de Cassation française, Civ. 1 ${ }^{\text {re }}, 11$ July 2018, nr 17-22.381

C de Terwangne and Q Van Enis, L'Europe des droits de l'homme à l'heure d'Internet (Brussels: Bruylant 2019)

J Deigh, « Punishment and proportionality: Part 2 » (2016) 35:1 Criminal Justice Ethics 21-38

J Deigh, « Punishment and proportionality » (2014) 33:3 Criminal Justice Ethics 185-199

M Delmas-Marty, Ordering Pluralism - A Conceptual Framework for Understanding the Transnational Legal World (Oxford: Hart 2009)

R Drath, «Hotfile, Megaupload, and the Future of Copyright on the Internet: What Can Cyberlockers Tell Us About DMCA Reform » (2012) 12 J Marshall Rev Intell Prop L 205

D Dyzenhaus, « Proportionality and deference in a culture of justification » in G Huscroft, B Miller and G Weber (eds), Proportionality and the rule of law - Rights, Justification, Reasoning (Cambridge: Cambridge University Press 2014) 234258

J Feinberg, Doing and Deserving (Princeton: Princeton University Press 1970) 102

M Finck, « Digital Co-Regulation: Designing a Supranational Legal Framework for the Platform Economy » (2018) 43 European Law Review 47-68

R Fisman, and L Michael, Fixing Discrimination in Online Marketplaces, HBR, no. December 2016

J Freeman, «Extending public law norms through privatization» (2003) 116:5 Harvard Law Review 1285-1352

C Geiger, and E Izyumenko, « The Role of Human Rights in Copyright Enforcement Online: Elaborating a Legal Framework for Website Blocking» (2016) 32:1 Am. U. Int'l L. R. 43

J Glaser, and K B Kahn, « Prejudice and Discrimination and the Internet » in Y Amichai-Hamburger (ed), The Social Net. Human Behavior in Cyberspace (Oxford: Oxford University Press 2005)

S Greer, «'Balancing' and the European Court of Human Rights: A Contribution to the Habermas-Alexy Debate » (2004) 63:2 Cambridge Law Journal 412-434

D Harvey, Collisions in the Digital Paradigm: Law and Rule Making in the Internet Age (Oxford/Portland: Bloomsbury Publishing, 2017)

S Hick, E. Halpin and E. Hoskins, Human Rights and the Internet (Palgrave Macmillan UK 2016)

SL Kaleda, «The Role of the Principle of Effective Judicial Protection in Relation to Website Blocking Injunctions » (2017) 8 JIPITEC 216

E Katsh and O Rabinovich-Einy, Digital Justice: Technology and the Internet of Disputes (New York: Oxford University Press 2017) 
B Kingsbury, N Krisch and R B Stewart, «The Emergence of Global Administrative Law » (2005) 68 Law and Contemp Probs 15

P Kjaer, «Why justification? The structure of public power in transnational contexts » (2017) (8:1) Transnational Legal Theory 8-21

M Klatt and M Meister, « Proportionality - A benefit to human rights - Remarks on the I-Con controversy » (2012) 10 Int'l J Const L 687-708

D Koukiadis, Reconstituting Internet Normativity. The Role of State, Private Actors, Global Online Community in the Production of Legal Norms (Baden-Baden: Nomos 2015)

K-H Ladeur, «A critique of balancing and the principle of proportionality in constitutional law - a case for 'impersonal rights'? » (2016) 7:2 Transnational legal theory 228-256.

L Lessig, Code 2.0. (Basic Books 2006)

E Marique and Y Marique, «Sanctions on digital platforms - beyond the public/private divide » (2019) 8:2 Cambridge Journal of International Law (forthcoming)

E Marique and Y Marique, «Beyond the Public and Private Divide on Digital Platforms? Revisiting Power Relationships » in E Bani, E Rutkowska-Tomaszewska and B Pachuca-Smulska (eds), Public Law and the Challenges of New Technologies and Digital Markets (CH Beck 2019 forthcoming)

E Marique and A Strowel, « Gouverner par la loi ou les algorithmes: de la norme générale de comportement au guidage rapproché des conduites » (2017) 10 Dalloz IP/IT 517-521

C Marsden, Internet Co-Regulation: European Law, Regulatory Governance and Legitimacy in Cyberspace (Cambridge: Cambridge University Press 2011)

D McKee, «The platform economy: natural, neutral, consensual and efficient? » (2017) 8:4 Transnational Legal Theory pp. $455-495$

H Oberdiek, "The Role of Sanctions and Coercion in Understanding Law and Legal Systems » (1976) 21:1 The American Journal of Jurisprudence 71-94

D Oliver, Common Values and the Public-Private Divide (Cambridge: Cambridge University Press 1999)

Paris Trial court, Ligue Contre le Racisme et l'Antisémitisme v Yahoo!, 20 November 2000

Przemyslaw J Palka, «Terms of Service are not Contracts - Beyond Contract Law in the Regulation of Online Platforms » in S Grundmann (ed) European Contract Law in the Digital Age, vol 3 (European Contract Law in the Digital Age, Intersentia 2018) 136-61

C Petersen, V Ulfbeck and O Hansen, « Platforms as Private Governance Systems - the Example of Airbnb » (2018) Nordic Journal of Commercial Law 38-61

S Quack, «Expertise and authority in transnational governance » in R Cotterrell and M del Mar (eds), Authority in Transnational Legal Theory - Theorising Across Disciplines (Cheltenham: Edward Elgar 2016) 361-386

C Reed, Making Laws for Cyberspace (Oxford: Oxford University Press 2012)

Report of the Special Rapporteur on the promotion and protection of the right to freedom of opinion and expression, 6 April 2018, Human Rights Council, 38 th session

Report of the Special Rapporteur on the promotion and protection of the right to freedom of opinion and expression, 16 May 2011, Human Rights Council, 17 th session

J Riordan, The Liability of Internet Intermediaries (Oxford: Oxford University Press 2016) 
C Rule, « Designing a Global Online Dispute Resolution System: Lessons Learned from eBay » (2017) 13:2 U St Thomas LJ 354-364

A Savin, EU Internet Law (Cheltenham: Edward Elgar 2013)

T Schulz, «Does Online Dispute Resolution Need Governmental Intervention? The Case for Architectures of Control and Trust» (2004) 6:1 North Carolina Journal of Law \& Technology 71-106

M Siegel, « Hate Speech, Civil Rights, and the Internet: The Jurisdictional and Human Rights Nightmare Comment » (1998-99) 2 Albany Law Journal of Science \& Technology 375-98

A Stone Sweet and J Mathews, «Proportionality balancing and global constitutionalism » (2008) 47 Colum J Transnat'l L 72-164

M Susi, «The Internet balancing formula » (2019) 25 European Law Journal 198-212

N Tusikov, Chokepoints: Global Private Regulation on the Internet (Univ of California Press 2016)

F Urbina, «Is it really that easy - A critique of proportionality and "balancing" as reasoning » (2014) 27:1 Canadian Journal of Law and Jurisprudence 167-192

M van de Kerchove, « Les fonctions de la sanction pénale. Entre droit et philosophie » (2005) 127:7 Informations sociales 22-31

R Van Loo, « Rise of the Digital Regulator» (2017) Duke Law Journal 1317

J Venturini, L Louzada, M Maciel, N Zingales, K Stylianou, and L Belli, Terms of Service and Human Rights: An Analysis of Online Platform Contracts (Editora Revan, Rio de Janeiro 2016)

A von Hirsch, « Proportionality in the philosophy of punishment» (1992) 16 Crime and Justice 55-98

G Vilaca, «Transnational legal normativity » in M Sellers and S Kirste (eds), Encyclopedia of the philosophy of law and social policy (Springer 2017)

J Waldron, «The rule of law and the importance of procedure » (2011) 50 Nomos, Getting to the rule of law, 3-31

C Wattecamps, A-G Kleczewski and E Marique, « Challenges related to law for the platform economy: A fresh look at some important dichotomies » (2017/3) Reflets et perspectives de la vie économique 57-95

Yahoo! Inc., v La Ligue Contre Le Racisme et l'Antisémitisme, 379 F 3d 1120 (9th Ct, 23 August 2004)

F Zuiderveen Borgesius, "Behavioural Sciences and the Regulation of Privacy on the Internet" in A Alemanno and AL Sibony (eds), Nudge and the Law (Oxford: Hart Publishing 2015) 